\title{
THE ESSENTIAL QUALITIES OF AN ANAESTHETIST*
}

Campbell Gardner, m D., C.M., f.r c.s. (eng ) \& (C), F.A C S.

MANY of you will, doubtless, feel that it is presumptuous for a Surgeon to talk of the "essental qualities of an Anaesthetist", as egotistical almost as if he declared that yellow roses were more beautiful than red! Therefore, you will agree that all that I can hope to do is to outline what one surgeon desires his partner anaesthetist to be.

Every surgeon has different likes and dislikes, all being prima donnas as you well know, therefore, I should never dare to venture to speak for all of them. However, having been a "quasi" anaesthetist myself, and having served as asșistant-anaesthetist overseas for a long period, and having come in contact during my lifetume with many of this breed of cat-good, bad and indifferent-I feel that I can at least enjoy myself at your expense, realizing full well that you will eventually have the last word, as I drift lazily off to sleep at the hands of one or other of you, while you playfully "lick your chops"!

In fact, I think that this is a most inter esting problem, and one I am sure which each of you has studied individually because, perhaps, no other branch of medicine has made such fabulous progress in the past fifteen years

It seems only yesterday that I' was training as an interne in the Montreal General Hospital, when all but one of the anaesthetists were nurses, with the exception of those of us who had little or no traming at all, but whom the poor, unfortunate patients accepted blissfully, believing that because we were doctors we really must be very superior beings. Any of you who can remember those days, when screaming children came to the Out-Door to have their tonsils removed in the morning, and we attempted to induce them with large amounts of open ether and still more physical force, must be encouraged indeed to see the immense progress that has been made.

I should like to quote here from one of the most famous English surgeons of today, Sir Heneage Ogilvie:

The most notable advance in the period I am reviewing, that of my own surgical career, has been in the field of anaesthesia. Anaesthesia has been advancing since its introduction in 1846, but the changes that have taken place in this field _n the last twenty years exceed those of the previous ninety. In my first ten years as an assistant surgeon many of my difficulties during the operation, much of my post-operative morbidity, and perhaps a cuarter of my post-operative deaths were due to the anaesthetic. As a junior surgeon - was unable to secure the services of a tramed anaesthetst, and had to depend on the services of any recently qualified man whom my housesurgeon was able to bring in. Most of my patients were terrified when they entered the theatre, strugghng durms induction, deep purple when they reached the table, stertorous and bubbling t.aroughout the operaton, unconscious and motionless during, the first six hours after they returned to the ward, vomitng for the next twelve, anc

\footnotetext{
"Presented at a meeting of the Quebec Division, Canadian Anaesthetists' Society, Queen Mary Veterans Hospital, Montreal, Que', February 12, 1955

${ }^{*}$ Chief Surgeon, Queen Mary Veterans Hospital, Montreal, Que
} 
chesty for the next week. So fearful was I of anaesthetacs that for twelve years, from 1927 to 1939 , I performed all my gastrectomes and much of my major surgery under local analgesia alone.

The modern anaesthetist gans the patient's confidence by a complete pre-operatuve overhaul, prepares him by a careful assessment and adjustment of his deficiencies, allays his fears by pre-operative medication, renders him unconscious by an intravenous barbiturate, maintains analgesia by one of the anaesthetic gases, ensures oxygenation and immobility of the diap.uragm by controlled respiration, and by the use of relaxants provides the degree of muscular relaxation needed at any stage of the operation. $\mathrm{He}$ is no longer a mere "dope merchant." He takes over the whole responsibulity for the patient's welfare and the surgeon's peace of mind. He presents the operator with tissues in a condition to suit him, relieves him of all anxiety except for the technical details of the operation itself, and hands him back a patient alive and well.

There is no question that Oglvie's opinion is shared by all the greater and more skilful surgeons of today, nor is there any doubt that the great decrease in mortality and morbidity, following surgery, is in large measure due to better anaesthesia. I do not believe that the surgeon of today is more skilful or dextrous than were those of the late nineteenth or the early twentieth century. In fact, I think they are a great deal less so, as men like Halsted, Lane, and Lister had to work against all sorts of difficulties caused by inadequate anaesthesia. Necessity for speed was paramount and I am told that even in this country it was quite common to amputate a leg in from three to five munutes. Many of the operations which have been reintroduced today were attempted and occasionally performed successfully fifty years ago, but could not be carred out satisfactorily with the anaesthesia practised at that time

Certanly we have come a long way along the road. What of the future?

When you ask me what are the essential qualities of an anaesthetist, I presume that you mean a perfect anaesthetist, and one realizes full well that such a paragon does not exist, but at least we should strive to produce hum. I think that you will agree with me that in the future anaesthetists and surgeons will share equal responsibility and receive equal compensation for a patient's welfare and if you wish as perfect a surgeon as possible to operate on you, it would seem only fair to expect the same of the anaesthetist.

Sympathy, honesty, strength, and skill-in that order-are the primary requisites of any able man, regardless of his calling, but these qualities are, perhaps, particularly desirous in an anaesthetist. Let me elucidate a little. A patient is naturally ternfied at the thought of an operation, but perhaps most frightened of the thought that he must go to sleep, not of his own free will, but on the intiation of someone else, and the horrid spectre is immediately conjured up that he may never wake again, or even if he does, that something dreadful may have happened to him in the meanwhile without his being able to protest Therefore, I would place sympathy, and I mean it in the true sense of the word-kindness and understanding-as the first quality to be desired. To be able to allay a person's fears, one must first be able to understand the individual and to put one's self in the patient's place. Once this is done, it is relatively easy to discount, one by one, the various "bogeys" which arise, and to all intents and purposes one has control of the patient's mind. I am sure you know enough of the 
tricks of the hypnotist to realıze that they are little more than this power carried to an extreme degree.

Honesty I think is an essential It is useless to tell a patient that really he is just going to have a little anaesthetic or a little cperation. To hım it is a terrifying experience and it is far better to place the carc.s on the table, to explain exactly what is likely to happen, and what methods you propose to use for combatng any dangers which may arise. It would seem wise to explain that he may awake to find himself with tubes protruding from every orifice in his body, and possibly with four or five needles introduced at various points through which solutions are running into him. There may be a mask or two over his face and a tent to cover all. If the patient has a clear understanding that this is all in the nature of things, and to be expected, he will usually accept it with calmness, feeling that the things which have been predicted have come true.

The late Dr. Elder once said that prognosis was infinutely more important than diagnosis. If you tell a patient, or his family, that he is going to die, you should make sure that even this comes truel While 1 would not recommend that you achieve this drastic result too often, I do feel that honesty certainly pays in your profession, as it does in ours.

Strength is a curious word and one often ill understood We are not discussing the physical strength of the bull or the bully, or the economic strength of the stock market manipulator but the great moral strength which allows an individual to give confidence and peace to those who are 11 or in trouble. This moral strength is indeed a phenomenon, difficult to define, yet of which we are extremely conscious. All who listened to Churchull deliver his famous speech before the fall of France could not help but be almost physically aware of the essential strength of the man and his belief, and themselves felt more capable of carrying on because of some almost metaphysical stimulus which he had imparted to them. This has been true of many of the great prophets and leaders throughout all time, and whule one does not expect every anaesthetsst to be able to rise to the heights on every occasion, nevertheless I feel that I, myself, would be terrified if I were about to be put to sleep by a tmorous man!

Strength may exıst in some fortunate individuals from birth, but it can be amplified by knowledge and by the feeling that one is' doing the best possible thing that can be done for the patient.

The most controversial essential is skill No doubt you raise your eyebrows because I name this fourth and not first. So much emphasis has been laicl on skill, and I should be the first to agree that wrthout some measure of skill, all the sympathy, honesty, and strength would be useless, but I feel that stress laid on its importance has tended to dwarf the other three essentrals. Medicine is not only a science, it is an art as well. However, we must accept the ability to perform one's job, an ablity acquired through hard work and orthodox training, as certainly an essential in any trade or profession

There are many different kinds of skills and it is almost impossible in a single lifetime to learn, or remember, them all. Dr. Penfield once stated that the brain was an organ for forgetting rather than for remembering-and although all of you, I am sure, did extremely well in your various primary courses during your 
college days, I wonder how many of you could rapidly enumerate the forty-two centres of the sense of smell, the comparative anatomy of dogfish and frog, the declension of a Latin noun, or even solve a simple problem in algebra. To try to help one's children with their homework is often a humiliating if stimulating task!

Although, therefore, it is desirable to have a good general knowledge of all subjects relating to medicine, because certainly this makes life more interesting, it is essental that you, like us, should concentrate to a certain extent at any rate on special subjects affecting your own specialty. Thus, I think, you will agree that some knowledge of physiology is almost essential to a good janaesthetist, particularly the physiology of respiration and circulation, whereas such knowledge is not so important to, let us say, the orthopaedic surgeon. It $/$ would seem important, too, that you have some general idea of physics, as you are dealing to such a large extent with gases and other inorganic compounds.

Must you know all about every disease which the body can contract and be competent to make a diagnosis by history and physical examination in each patient you are asked to see? Many think you should. Some physicians and surgeons, on the other hand, are often apt to take umbrage when an anaesthetist decides to make a complete preoperative examnation of their patient. They feel it is none of his business and perhaps are secretly perturbed that he might turn up so nething they have missed!

Your best course of action probably lies between not seemg the patient at all and takıng him over completely.

Skulful diagnosticians and therapists, very often, make a correct diagnosis and suggest treatment from facts related to them over the telephone and there seems no reason why, if you have confidence in a physician or a surgeon, you should not accept his findings and relate them to the type of anaesthetic that you desire to use, looking only for the extra information you may requre. It would seem only necessary to amass a separate detalled history and physical report if the patient appears, from the record, to be very lll. In such a case the anaesthetist might wish to have certain special exammations made with a view to determining the risk involved This, perhaps, can best be done in consultation with the physician, or the surgeon, concerned

As regards the actual technique of giving anaesthetics, I have little to say. Very like surgical operatıve techniques, anaesthetıc technique is perhaps the least important part of the whole job Nevertheless, you become very bored and sometimes quite irntated by a surgeon, who cannot or will not get on with his job simply because he is too lazy or lacks the necessary skall, so too it would seem that there is still room for improvement in the technque of some anaesthetists with whom I have come in contact, particularly in their ability to introduce needles into veins quickly, or to enter a spinal canal without having the patient jump off the table and fracture his skull.

Another technique which, I have noticed, is not always perfect, is the insertion of an intratracheal tube, and I have had to explain to patients on several occasions (I must say not without some chagrin) why two or three of the best 
front teeth in the world are missing, this being necessary to the success of the operation!

It would seem, too, that considerable care should be taken before the operation begins to place the patent in a position where veins are accessible, even though the surgeon ndicules the idea. He will be the first to blame you if an arm has to be produced from under the drapes thereby forcing him to stop his headlong course. During the operation it would seem unwise to suggest to this poor benighted creature, just after he has divided the common duct, ligated the aorta by mistake, or committed some other such fearsome error, that the patient is not doing very well! Nothing is more apt to spread alarm and despondency throughout the whole team Do what you can to help and when the emergency is over, tactfully suggest that mayhap today is not the one slated in the stars for the completion of this partıcular operation.

As far as the postoperative care is concerned we have in this hospital, as you know, a Recovery or Resuscitation Room, whichever you prefer, which has perhaps made the greatest single contribution in decreasing our mortality and morbidity since the war There was a good deal of criticism by many of the surgeons when we decided to place this room in charge of the Chief Anaesthetist. However, a happy compromise was reached when it was agreed that the surgeton should have the right, at any tme, to go in and write the orders for his patient The anaesthetsst would only issue the necessary instructions if the surgeon failed to do so. Needless to say, since the Recovery Room has been opened, to my knowledge no single order has ever been written by a surgeon, and the Recovery Room is now universally approved by everyone Surely this is a great tribute to the progress of anaesthesia.

What other skalls should an anaesthetist haver

Presumably the abılity to diagnose peripheral vascular diseases and assess the value of his blocks on such cenditions. He must, too, have a wide knowledge of anatomy in order to use local anaesthetics properly.

He must necessarily be a well-trained and imaginative research worker because, after all, anaesthesia is but at the beginning of its road. There is no reason, it would seem to me, why since you gentlenen have mastered the problem of artficial sleep, you should not solve the riddle of natural sleep and relaxaton, and thereby save all of us from having the diseases which tension is so likely to cause at the present time

The following group of qualities do not, perhaps, fall into the realm of actual sklls but surely a good anaesthetist should be master of them all. He should have infinite patience, even though suffering the most frightful boredom when a longwinded, laborious, slow-witted surgeon takes hours to do things which he, himself, could do in minutes! He shou d have a sense of humour eapable of gently pacifying the most ruffled nurse and yet he must be careful not to use this at a time when a laugh is like the rasping of a file on the jangled nerves of a surgeon faced with a situation from which he has no idea how to extricate himself. The good anaesthetist must have the ability to get along with his fellow men and women, and be capable of organizing his department so that everyone is com- 
pletely happy, and yet accomplish this in such a way that he makes everyone else feel they are actually handling the situation. In other words, he must learn to be a co-ordinator, not a durector. He must be adaptable, a quality well sllustrated by what occurred during the past war, when one was transported from all the comforts and assistances which were provided in civilian life into makeshift operating rooms and quarters where one literally had to scrub the floors before one could even start to think of one's own equipment.

Undoubtedly, the essential qualities of an anaesthetist must vary deperiding upon the situation in whrch he finds hirnself. Whereas in a university hospital he should have all the qualities previously described plus the ability to teach, in a smaller hospital some of these are not essential and others only to a moderate degree.

Just recently $I$ asked the wife of a friend of mine whom I had traned and who is now doing surgery in a large town, how he was getting on. To my astonishment she burst into tears and said she was terribly disturbed because he had lost three of his last twelve gastrectomes and she wondered if he should not return for further traming I asked her a few questions about the hospital and the community and my suggestion to her was a simple one, that my friend should take some of the money which he was rapidly accumulating and associate himself with a first-class anaesthetist I felt then that his troubles would be over In fact he accepted my suggestion, the desired result has been achieved, and his income has increased greatly despite the added experise.

I know perfectly well that you realize that what I have said is partially in a jokng mood because it must be obvious to you, as it is to me, that a mar. possessing all the qualities which $I$ have enumerated would not be a man at all but a veritable god However, I have at least attempted to outline the possibilities that you may all strive for. As Browning said,
Ah' but a man's reach should exceed his grasp,
Or what's a heaven for.

In summary one might say:

Show me a man with sympathy, honesty, strength and a moderate amount of skill, who is interested (1) in the welfare of the pattent, (2) in the team of which he is a part, and ( 3 ) in the profession of medicine as a whole and in the institution to which he belongs, and I am quite certain not only that he will have the essential qualities of a wonderful anaesthetist but that his own success and that of the anaesthesiology in his community will be assured.

\section{RÉSUMÉ}

Les qualités qui définissent un homme de valeur quelque soit sa profession et qui sont particulıèrement essentielles chez l'anesthésiste sont la sympathie, l'honnêteté, la force et l'habilité.

La sympathie dans le vrai sens de l'amabilité et de la compréhension est essentielle si l'on veut apaiser la crainte naturelle du patent pour un sommeil que ne vient pas de lui mais par la volonté d'un autre.

L'honnêteté s'impose. Il est inutile d'essayer de faire croire au patient qu'il va avoir seulement une courte anesthésie ou une petite opération quand pour 
lui n'importe laquelle opération est terrifiante. Il est préférable de lui dire exactement ce qui va se passer.

La force morale requise est celle qui inspire confiance et paix à ceux qui sont malades ou qui ont du troubles. Elle se définit difficilement bien qu'on la détecte aisément. De tous les temps, cette qualıté a été un attribut des grandes chefs. On ne doit certes pas s'attendre que l'anesthésiste atteigne le sublime à chaque occasion, il n'en reste pas moins qu ón serait effrayé à la pensée d'être endormi par un homme timoré.

L'habilité est la qualité qui soulève le plus de controverse. Bien qu'il soit vrai que sans l'habilité, la sympathie, l'honnêteté et la force morale seraient inutiles, 1 l n'en demeure pas moins vral que l'habilité est la qualité la plus facile à acquérrr. D'autre part la force s'augmente quand on a la connaissance et l'habilité qui donnent le sentment qu'on fait le mieux possible sour le patient.

En plus de ces qualités majeures, l'anesthésiste doit pcsséder de la patience, le sens de l'humour et doit être capable de s'accorder avec les autres gens.

Qu'on me montre un homme qui est sympathique, honnête; qui a de la force morale et quı est suffisamment habile, qui sintéresse au bien-être du patient, à l'équipe dont il fait partie, à la profession médıcale elle-même et enfin, à l'institution pour laquelle 1 l travalle - cet homme j’en sus certain, a les qualités essentrelles pour être un mervellleux anesthésiste. 